\title{
MAGYARORSZÁG BELSŐ GYARMATOSÍTÁSA
}

\section{MIKLÓSSY ENDRE}

A hatvanas évek eleje óta különféle megfogalmazásokban, de szinte állandóan szerepel a fejlesztési célok között a ,területi aránytalanságok leküzdése”. Ennek ellenére a nyolcvanas évtizedben - ahelyett, hogy a joggal várható kiegyenlítôdés okozta problémákkal kellene küszködni - külön fejlesztési programot kellett készíteni a területi elmaradottság mérséklésére.

Úgy gondolom, hogy az ellentmondás oka a szisztéma alapjaiban van, nem pedig esetleges múködési zavaraiban. Meg kell ezért kísérelni a leírást a gazdaság egészének múködésével kapcsolatban. Ebben Kornai János Hiány címủ könyvének egyik példáját használtam fel, az ott alkalmazott jelentés némi módosított általánosításával:

— egy üzem szũkebb értelemben vett árutermelésérổl a társadalmi újratermelés egészére;

- a pillanatnyilag érzékelhetố, illetổleg krónikusan újratermelổdổ erơforrás-korláttól addig a több évtizedes folyamatig, amíg a forrás valóban kimerül.

A nemzetgazdaság fố sajátossága, hogy központilag vezérelt hiánygazdaság, amelybổl számunkra a legfontosabb a szisztéma ráfordítás iránti érzéketlensége. Ez abból adódik, hogy a központilag vezérelt hiánygazdaságnak módjában áll a ráfordítások tekintélyes hányadát externalitásként kezelni, és éppen ez a regionális elmaradottság meghatározó oka.

A kérdést Kornai (1982) nyomán a kapacitáskihasználás felöl közelíthetjük meg. Egy termelố üzem esetében a költségtényezô a kapacitáskihasználás függvényében a következố (l. ábra):

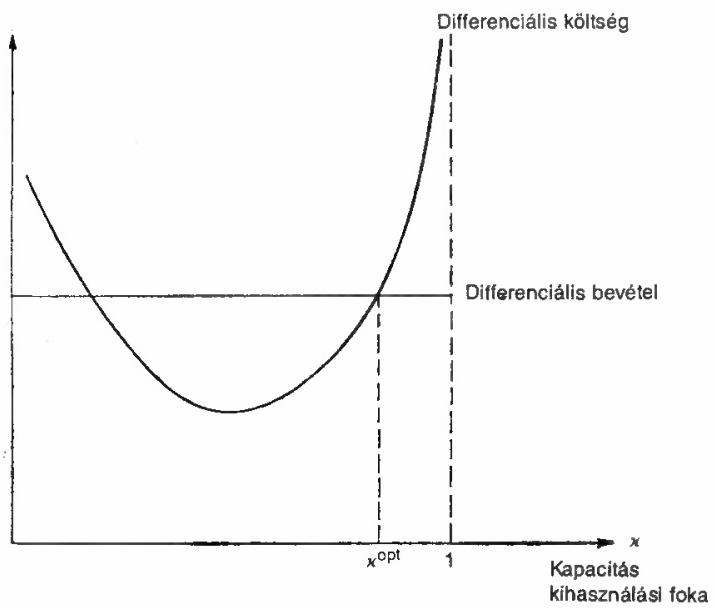

1. ÁBRA

Forrás: Kornai 1982: 280. o.

*A tanulmány OTKA pályázat kutatási anyaga nyomán készült. 
A költségek, illetve általában a ráfordítások minimuma nem a maximális kapacitáson van, hanem alatta. Mi az oka akkor a , feszített" kapacitáskihasználásnak? Kornai szerint az alábbiak (A hiány, 299-303. o.):

1. A többlethaszon biztos és tervezhetố is, pl. mint tervtúlteljesítés.

2. A többlethaszon túlnyomó részt belsố, azaz megjelenik a rendelkezố fél közvetlen eredményében (bevétel, presztizs stb.). A többletráfordítás ellenben túlnyomó részben külsố, externális (pl. társadalmi munkaidôalap növekvố felhasználása).

3. A többlethaszon központilag jelenik meg, a többletráfordítás ellenben atomizáltan, egyedeknél, kisebb és anonim közösségeknél, témakörönként is elkülönülve (lakáshelyzet, környezetszennyezés, egészségügyi ellátás stb.).

4. A többlethaszon azonnali, a többletráfordítás viszont idôben késleltetett (pl. a géppark gyorsabb ütemü tönkremenetele). Hogy megértsük, milyen társadalmi-területi következményei vannak e feszítettségnek, vezessük be Kornai nyomán a , jóléti függvény” fogalmát (294 o.), amivel a társadalmi optimum szemléletessé tehetô. A séma meglehetôsen absztrakt, tekintettel egyebek közt arra, hogy a "jólét" számos tényezôje szubjektív és nem is számszerüsíthetố. Termelố üzem esetén a kiinduló séma a következó (2. ábra):

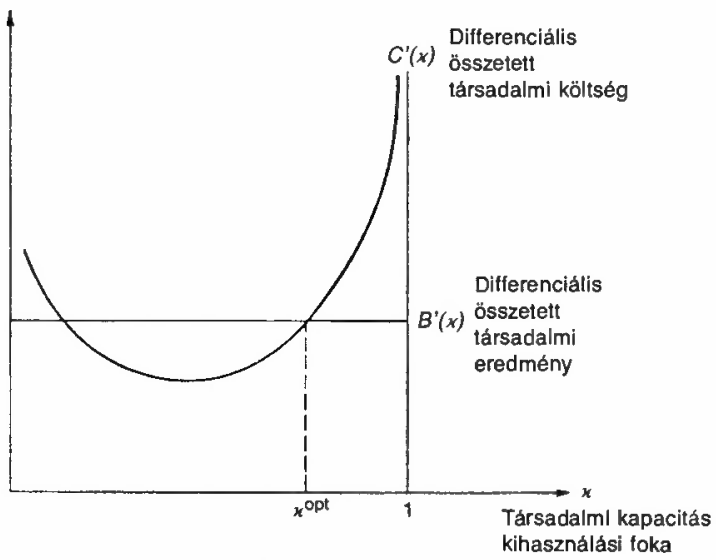

2. ÁBRA

Forrás: Kornai 1982: 295. o.

A fajlagos bevétel nem függ a kapacitáskihasználástól, a költségfüggvény pedig U alakú. A kapacitásmaximum közelében a költség felülmúlja a bevételt. Az ,optimumot” a két görbe metszéspontja adja. Feszített kapacitáskihasználásnál a fajlagos költségek növekednek ( $\left.\mathrm{K}_{\mathrm{eff}}\right)$.

Lényegében ugyanez a séma érvényes a társadalmi termelési folyamat egészére, amelyre vonatkozóan

- a differenciált összetett társadalmi költséget, illetve

- a differenciált összetett társadalmi eredményt ábrázolja.

Kornai azonban fölveti: ,,Önkényes volt feltételezni azt is, hogy a C' differenciális összetett társadalmi költségfüggvény U alakú. Csak akkor U alakú, ha azok, akiknek értékítéleteit ez 
a jóléti függvény kifejezi, elismerik a növekvố differenciális társadalmi költséget" - mondja (i.m. 296. o.). Ha ellenben ezt bagatellizáljuk, akkor a görbe alakja ilyen (3. ábra):

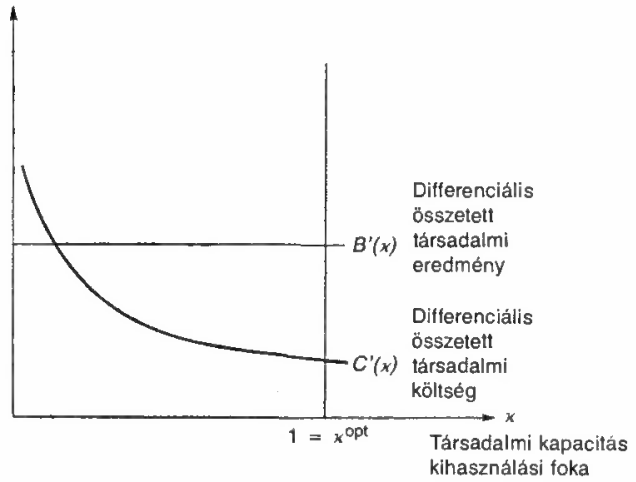

3. ÁBRA

Forrás: Kornai 1982: 297. o.

Vagyis az optimum a maximummal esik egybe, és így a korlátlan expanzió a cél.

Úgy vélem azonban, hogy a ,,növekvô differenciális társadalmi költséget” leginkább akkor hajlandó az ember bagatellizálni, hogyha mások költségeirôl van szó. Például ritka az, aki a száraz kenyeret és a szögesdrótot optimálisnak tekintené a saját maga számára. Megkockáztatnám ezért azt az állítást: akik az iskolakörzetesítést a "tiszta ész", avagy a nemzetgazdaság szempontjából kitalálták és elrendelték, saját maguk nem bekörzetesített iskolájú faluban laknak.

Maradjunk így inkább a következô sémánál: a görbék alakja hasonlóan $U$ alakú minden esetben, csak paramétereik különböznek. Képzeljük el, hogy valaki szabályozhatja egyes egyének, termelôegységek költségeit és eredményeit. A népgazdasági átlag természetesen változatlan, a feszített kapacitáskihasználás is, mégis kijöhet az egyéni optimum (4. ábra):

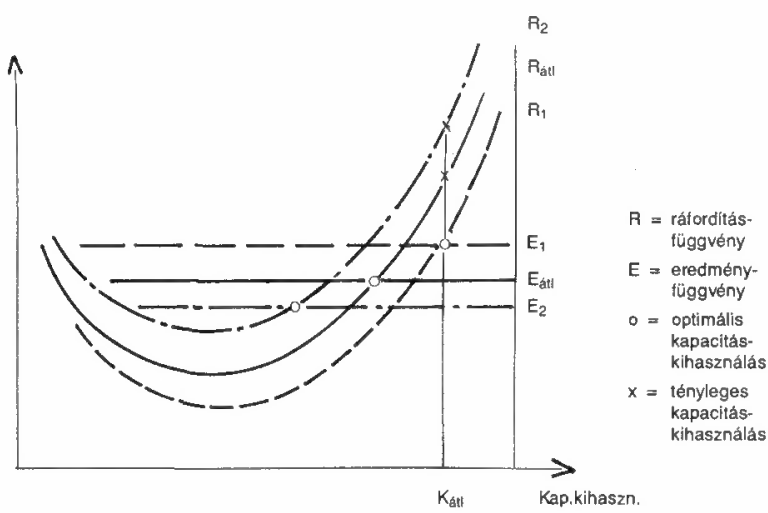

4. ÁBRA 
Amennyiben egy szereplổnek lehetốsége van arra, hogy relatíve csökkentse ráfordításait és növelje eredményeit, akkor nemzetgazdaságilag feszített kapacitás mellett is elérheti (a maga számára) az optimumot ( $R_{1}$ és $E_{1}$ metszéspontja). Ha ez nem jár az átlagfüggvények kedvezô módosításával ( $\mathrm{R}$ csökkentés, $\mathrm{E}$ növelés), akkor csakis mások rovására mehet, vagyis a többi

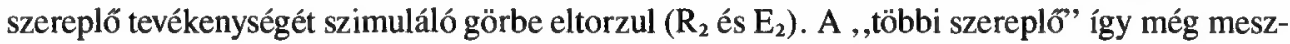
szebb kerül saját optimális kapacitáskihasználási pontjától, azaz még feszítettebb lesz a tevékenysége, és még nagyobb a ráfordítása.

A ráfordítások csökkentése népgazdaságilag közismerten nem megy. ${ }^{1}$ A Kornai által leírt korlátlan keresletbôl és ,,puha” költségvetési korlátból ez nyilvánvalóan következik. Az eredmények növelése még kevésbé megy, mivel a világgazdaság folyamatosan, tartós (és gyorsuló) tendenciaként leértékeli a termékstruktúrát. Marad tehát a harmadik lehetôség: a ,,szivattyú". A ,,szivattyư" a hidraulikában a potenciálkülönbség mesterséges fenntartására szolgáló eszköz. Alkalmas szemléltetố fogalma ezért a társadalmi-gazdasági folyamatok gerjesztett egyenlốtlenség-rendszerének. A területi egyenlốtlenségek jellemzésére a nyolcvanas évek óta használatos (Miklóssy 1987). A ,szivattyú" léte alapvetôen társadalmi-politikai kérdés, hiszen fenntartásához nélkülözhetetlenek a hatalmi eszközök. Egy hatalmi kontroll nélküli gazdaság tartósan diszpreferált szereplôi ugyanis bizonyosan elmozdulnának saját ,,optimális kapacitásfelhasználásuk" irányába. Egy ilyen fordulat az ebben a modellben leírt gazdasági rendszer esetében minden valószínũség szerint jelentősen csökkentené a társadalmi összterméket. Magát a ,,szivattyút" azonban csak a legszélsőségesebb sztálini idốkben múködtette közvetlenül a hatalom. Általában a gazdaság- és társadalompolitika preferenciarendszerei töltik be a szivattyú szerepét.

Az egyenlốtlenség fenntartásában természetesen nem egyének, vagy társadalmi rétegek haszonszerzése a fố cél, hanem a ,feszítettség” állapotának fenntartása. Az „optimumot” egy nemzetgazdasági ágazat számára kell biztosítani. Ez természetesen az elsổ szektor, pontosabban annak is a kiemelt része, pl. a hadiipar, illetôleg általában az alapanyagipar.

A területi következményekre késốbb visszatérünk. Most meg kell vizsgálnunk a ,,szivattyú" tényleges múködését. Ennek két, egymástól elvileg független eleme:

- a haszonfüggvény emelése;

- a költségfüggvény süllyesztése.

\section{A haszonfüggvény emelése}

1. Közismert, klasszikus formája az agrárolló, ami eredeti formájában az ipari tớke magasabbfokú szervezettségének és jobb érdekérvényesítési pozíciójának következménye. Erổforrás-korlátos gazdaságban van azonban egy még erôsebb, magában a rendszerben rejlố ilyen kényszerítés. A két szféra a piacon tökéletesen egyenlốtlen helyzetben van.

2. ,,Szívást”, tehát a kereslet korlátlan növelését csak az elsổ szektorba tartozó termékeket elôállító ipar érzékelhet, hiszen ezek felvevởi csak ,,puha" költségvetési korláttal találkoznak. A második szektorba tartozó termékek (fogyasztási cikkek) és ezen belül a mezôgazdaság produktumai azonban beleütköznek a háztartások , ,kemény" költségvetési korlátjába. (A szocialis- 
ta relációjú külkereskedelem figyelembe vétele ezt a sajátosságot alkalmasint még jobban elmélyíti.)

3. Ide tartoznak a termeléstámogatások, exportprémium, importdotálás stb. is, amelyek értelemszerủen a költségvetési hányad növekedésével (az elvonások emelkedésével) járnak.

4. Sajátos magyar formáció az ipari telephelyi rendszer. A telephely technológiai részfeladatot végez az anyaüzem számára, a belsỏ elszámolási rendszer eképpen vállalaton belül képes a haszonfüggvényt a telephely rovására módosítani. (A mozgatóerô itt a kényszerkapcsolat, vagyis a piac kiiktatása.) Azt lehet mondani, hogy externalitássá változik ezen a módon magának a termelési folyamatnak egy része is. ${ }^{2}$

\section{A költségfüggvény süllyesztése}

Nemzetgazdasági szempontból ide tartozik minden ,, halasztás”, valamint azon többletráfordítások összessége, amely a munkavállalókból kiszorítható. Nem utolsó sorban ide tartozik a kiemelt célokat szolgáló infrastruktúra-allokáció is. Területi szempontból ennek van a legnagyobb jelentôsége. Az elmúlt évtizedekben a központi redisztribució (a források teljes elvonása és újraelosztása) szabályozta. Döntố volt a munkaerôpolitika szempontjából, amit nagy mértékben lehet állami forrású lakásépítéssel orientálni. Ez tulajdonképpen jórészt nem egyéb, mint a preferált tevékenység közvetlen költségvetési támogatása. ${ }^{3}$ Népszerũ is, hiszen úgy tưnik, mintha egy alapvetổ szociális probléma megoldását segítené. ${ }^{4}$

Az allokáció alapja az infrastruktúra közismert központosítása: a létesítményeké, az összekapcsoló szerkezeti vonalaké. A centralizációban a periféria többletráfordításai érdektelennek tûnnek, mivel externalitások. ${ }^{5} \mathrm{Az}$ infrastruktúra fejlesztés, nagyrészt költségvetési forrású lévén, különösen alkalmas a kiemelt ágazatok relatív költségeinek csökkentésére. Amit az elmúlt évtizedekben , ,a területfejlesztés gazdaságossági kritériumain" értettek, az éppen a kiemelt tevékenységek fejlesztésének alátámasztása volt. ${ }^{6}$ (Ahogy azt az alapsémánkon láttuk, ez nern egyéb, mint a többinek a diszpreferálása.)

Természetesen direkt költségcsökkentố szisztémák is vannak. A pénzügyi szabályozás preferenciáival, amelyek ezek közül a legfontosabbak, itt nem foglalkozunk. Közvetlen területi költségszivattyú ellenben a fốvárosban és a falvakban jelentôsen eltérõ elektromos díjszabás. Ez jól ismert tény; az ellenben, hogy maga az infrastruktúra kiépültsége miképpen preferálja a fôvárosi termelốket a vidékiek rovására, sokkal kevésbé, pedig összességében lényegesen számottevốbb tétel. ${ }^{7}$

A , ,szivattyút”, a ráfordítások szintjében meglévô relatív különbségek mesterséges fenntartását, az egyenlốtlenségek táplálják. ${ }^{8}$ Kétségkívül a legsajátosabb egyenlốtlenség az, amikor nem egyszerūen ,,elhalasztott fejlesztés" van, hanem visszafejlesztés. ${ }^{9}$ Mindez a korszerû̉sés :-: nagyobb méret = központosítás axiómára való hivatkozással történik, mechanikusan, azaz minden tényleges, konkrét értékelés nélkül. Elôfordulhat ugyan a , korszerüsítés” eredményeképpen kimutatható "gazdaságossági"' elem, pl.: csökkenô üzemeltetési költség. Az esetek nagy részében azonban ez is látszólagos, mivel a többletberuházás nem szerepel a kalkulá. cióban. ${ }^{10}$ 
Ennél is fontosabb következmény a centrum relatív fölértékelése, ani ot csökkenti a fajlagos ráfordításokat. $\mathrm{Az}$, externalitásokban" is, és ez társadalmilag döntố ôntısságú. Ugyanis a tár-* sadalom externális tartalékait ez mozdítja el a centrum irányába. " A , w'vattyú olyan nagy mértékben megaöveli a területek közötti esélykülönbséget - a haszon a ráfordítás eltorzitásával -, hogy az a táisadalom deformálódását eredményezi. ${ }^{12}$ Term sà tesen az is lehetséges, hogy a folyamat elôrehaladtával a preferált és diszpreferált társadialon cyszerúen két részre esik szét, területileğ is. és így az ország kitermeli a maga , négerproblénłiłát”, amin már nem csupán a cigányok lesżnek értendők.

\section{$A$,szivattyú" és az elmaradottság kapciolata}

A nemzetgazdaság négy fejlôdési fázisában ${ }^{13}$ az elmariılottság meglehetôsen eltérô módon jelenik meg, habár közös alap, hogy a ,fồ' tevékenysệ̂hez kçposi mincen esetben többékevésbé externalitásként szerepel.

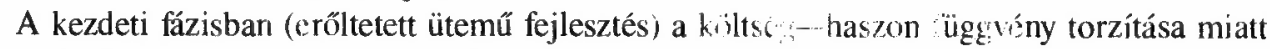
a periférián növekvố tényleges eredményhez csökkenô rádordítá tartozik. Ennek általában a

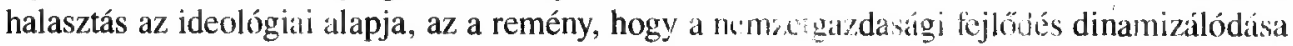
késôbb majd itt is forrást teremt a növekvố ütemú fijles',tishez, vagy is , visszatáplal”. De ez ellen szól a gazdaságtejlődés belsó logikája. Mint littuk, a követkecó cililus forrása minılig az elôzổ amortizációs alapja. Ezért a ,reménybeli" házis clmatrar, é: helyetre két ẹgészen más dolog történik:

- Az egyik, hogy a nemzetgazdasági fejlődés nem dinariziłlóđik. A mágus GNP aövekedési ütem önmagában nem tekinthetố annak, hiszen csı̀ egyre magassibb róiordítások árán lehetséges.

- A másik, hogy a diszpreferencia az eredményt is visszaszorít a a 'vriférián, így a fejlesztés gazdaságilag sem indokolható. A séma a következó: (5. abra)

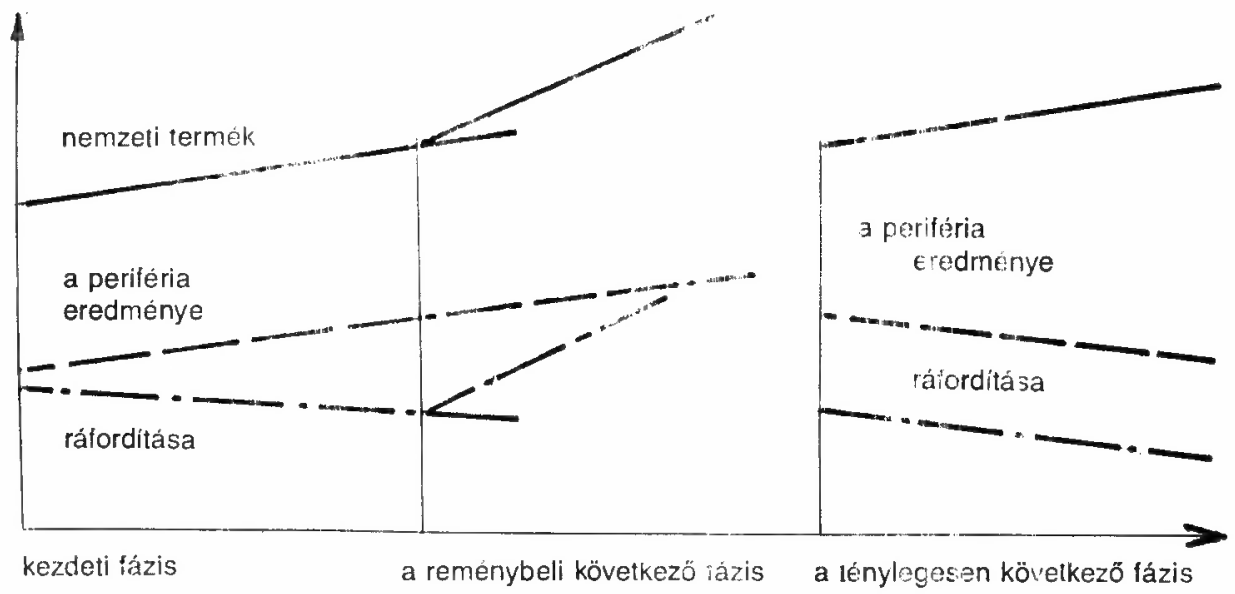

5. ÁBRA 
Ebben az elsố fázisban az elmaradottság kialakulása vagy megerősödése hatalmi-politikai kérdés. Ismeretes a központi redisztribúció rendkívül stabil bázisszemlélete, amelyben a kialakult arányok a tehetetlenség miatt sok évtizedre rögzốdnek. A mai Magyarország fổ beruházási arányai például alig különböznek az 1950-estôl. Így az elmaradott térség egyszer kialakult kedvezốtlen részesedése öröklődik. A , halasztás" mindjobban kitolódik, egészen addig, amíg mint láttuk - a számításba vehetố gazdasági haszon is elenyészik. Így lehet belôle végleges elmaradás. A fejlesztéspolitika ,,eredménye” pedig immár visszafordíthatatlan destrukturálódás.

A második fázis, amelyet külsố forrásbevonó fejlesztési optimizmus jellemez, regionális szempontból éppenséggel összehúzódással jár. ${ }^{14}$ Tulajdonképpen arról van szó, hogy az elmaradt föllendülés további externalitások igénybevételére ösztökél.

A harmadik fázist, amikor a növekedés megáll, egyértelműen még nem tudjuk áttekinteni. Annyi biztos, hogy létezik egy talán minden eddiginél erôsebb centralizáció, amelyet azonban itt talán nem közvetlenül a forrásösszpontosítás motivál, hanem a takarékosság. Itt már valóban megkísérlik csökkenteni a ráfordításokat, de - természetesen - ez is elsősorban a periféria rovására történik. ${ }^{15}$ Ebben a helyzetben már fölismerik a kompenzáció szükségességét, például központi alapot hoznak létre az elmaradott térségek támogatására. ${ }^{16}$

Úgy gondolom azonban, e kérdés semmiképpen se kezelhetố függetlenül a nemzetgazdaság egészének megújításától, mert a kialakult szisztémák az externalitások fölélésével azonnal megsemmisítik a kompenzáció minden lehetôségét.

\section{Mi a teendó?}

Itt mindenekelốtt meg kell néznünk, milyen összhatása van a fejlesztéspolitika által múködtetett szivattyúnak a periférián. A regionális elmaradottság kérdései a ,területi” típusú erôforrásokkal függenek össze. Az eróforrásokat négy fố típusra oszthatjuk:

- folyamatosan bốvíthetổ (ilyen pl. a tôkkefelhalmozás);

- korlátos, aminek a fajtái megújuló (pl. mezôgazdasági termelốképesség); elhasználódó; elfogyó (pl. bányakincs).

A ,területi” típusú erôforrások megújuló, vagy elhasználódó jellegưek, tehát ezt a két esetet kell megvizsgálnunk. (6. ábra)

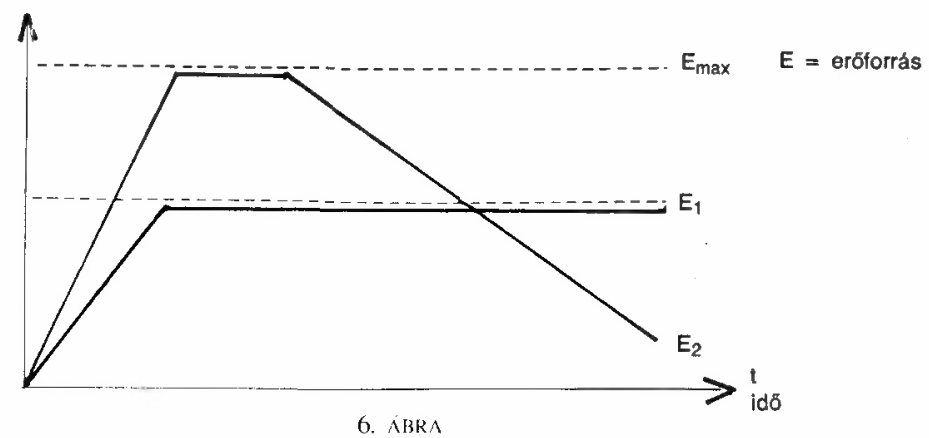


$\mathrm{E}_{1}=\mathbf{a}$ feltárt erőforrás egy bizonyos szintig növekszik, onnan kezdve stagnál. Ez azonbản szinttartó, vagyis a forrás önmagát újratermeli. A szint az erôforrás elvben lehetséges maximumánál mindig alacsonyabb.

$E_{2}=a$ feltárt erôforrás a maximumig nô. Mivel azonban eközben föléli a megújulás forrásait, innen kezdve, esetleg egy bizonyos átmeneti idốszak után, csökkennie kell. A csökkenésnek elvileg nincs alsó határa, tehát a teljes elfogyásig tarthat, valószínũ azonban, hogy létezik olyan küszöb, ami bizonyos strukturális átalakulást okoz, ami - egy alacsony szinten - a forrást szinttartóvá változtatja. ${ }^{17} \mathrm{~A}$ pozitív beavatkozás lényege a fölélés megállítása és a forrás stabilizálása, lehetốség szerint minél magasabb szinten. (Sémánkban ez az aszimptota , ,helyrebillentését" jelenti, ez felel meg a forrás ,,megújuló” típusú átalakításának.) A szint valószínüleg alacsonyabb annál, mint amit az eredeti megújuló szint adott volna. A különbözet a ráfordításérzéketlen extenzív fejlesztés ,ára".

Megkíséreltük kimutatni, hogy a ,,területi szivattyú" és a nyomában járó regionális elmaradottság éppen efféle átalakulást eredményez, vagyis elhasználódó típusúvá alakítja a forrást. A feladat lényege ebbôl adódik: az aszimptota helyrebillentése.

Az elmaradott térségek fejlesztésének hivatkozási alapja ez utóbbi években az állapolgári jog, az esélyegyenlőség stb. Elhibázottnak tartom ezt, mert nemzetgazdasági szempontból e kategóriák irrelevánsak. (Az elmaradott térségek fejlesztése így olyan kategóriába kerül, mint mondjuk az alacsony nyugdíjak reálértékének a megôrzése.) Így aztán a magasztos elv mindig fenntartható (a távoli jövổre nézvést), míg a nemzetgazdaság — súlyos mindennapi gondjai miatt - nyugodtan teheti az ellenkezôjét.

A kérdést alapvetổen nemzetgazdasági szempontból kell föltenni. Ekkor viszont a következố nehézséggel találkozunk: Az elmaradott térségekben felhasználható ,,potenciális erôforrástartalékok" nincsenek. (Amennyiben vannak, bizonyíthatóan igen csekélyek, avagy nemzetgazdaságilag nézve igen periférikusak.) De még ha volnának is, ez csupán egy újabb erôforrásra terjesztené ki a ,,szivattyúhatást”, vagyis nem oldaná meg magukat a problémákat, csupán a bajok jelentkezését tolná ki egy újabb időhatárig. Ebbe a szisztémába ezért kár újabb forrást beépiteni, még ha föltárható volna is. A hatékonysági stratégia megváltozása nélkül az elmaradott térségek fejlesztése tulajdonképpen nem lehetséges, sốt, talán nem is kívánatos, mert a fejlesztốeszköz esetleg csak újabb veszteségforrássá válik. (Ha az egész nem gazdaságos, akkor aligha lehet egy részét gazdaságosan fejleszteni. Lásd például a Sajóvölgy helyzetét.)

Tárgyunkon belül a hatékonyság kulcskérdése az externalitások internné alakítása. Tulajdonképpen azoknak a kényszereknek a megszüntetése kell hozzá, amelyek a ,területi szivattyút" müködtetik:

— a központosított fizikai térszerkezet oldása a lokális kapcsolatok vonalainak kiépítésével;

- az ipari telephelyrendszer kényszervertikumának megszüntetése;

- a rejtett termeléstámogatások megszüntetése, valóságos árviszonyok kialakítása;

- a dotációk területi különbségeinek kiegyenlítése;

- az infrastruktúrában mesterségesen kialakított szintkülönbségek felszámolása;

- a fejlesztési források redisztribúciója által okozott hatalmas különbségek nivellációja.

Mindez, esélyegyenlôség formájában, végeredményben a valóságos piac létrejöttének egyik alapfeltétele. Persze az a kellemetlen benne, hogy a látható ráfordításokat ugrásszerủen megnöveli. 
Ugyanakkor, a nemzetgazdaság szempontjából tulajdonképpen nincs is externalitás. Ezért itt voltaképp azon monopolhelyzetek megszüntetésérôl van szó, amelyekben a privilegizáltaknak módjukban áll mások ráfordításait annak tekinteni, a maguk okozta költségeiket másokra hárítani. Az ebbốl származó haszon — azaz megnyíló-megốrzôdô tỏbbleterôforrás - elvben óriási lehet, bár kétségkívül nem a mesterségesen fenntartott privilégiumok számára.

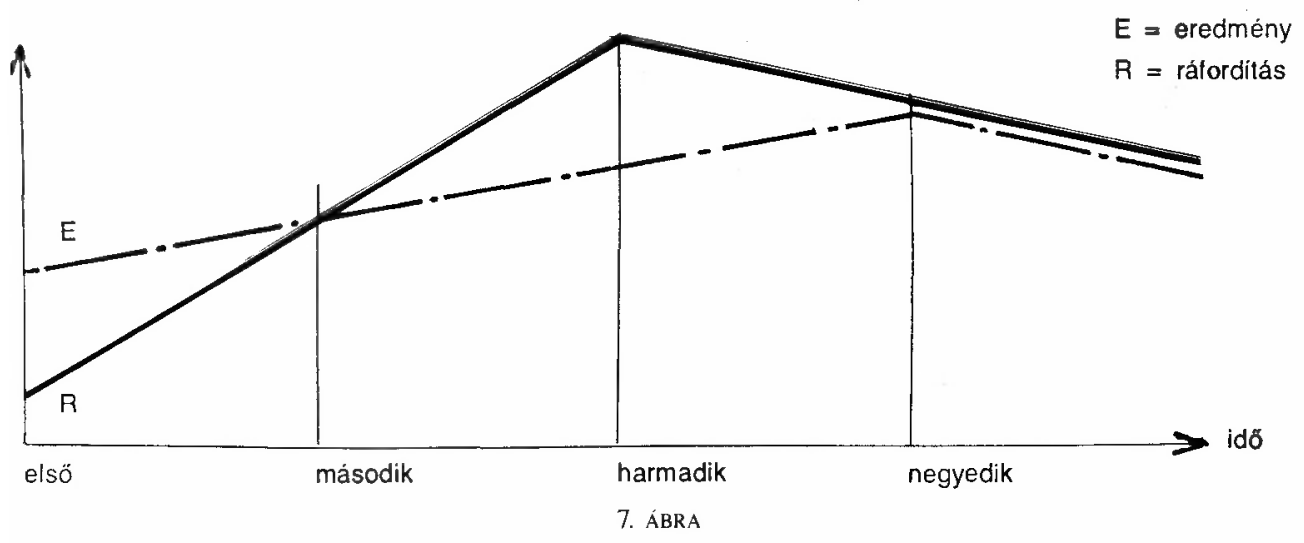

\section{Jegyzetek}

1 Magyarországon a hat vanas évek elsô felében nagy erốfeszítéseket tettek a ráfordítások csökkentésére, valószínủleg elöre látva a munkaerơforrások várható közeli kimerülését:

Két példa:

- a lakásépítés árindexe 1962-ben -5, 1963-ban -2,7, 1964-ben -0,3\%. Ilyen nem volt sem azelôtt, sem azután (saját számítások a Statisztikai Évkönyvekbở);

- a fốvárosi közlekedés költségvetési dotációja 1965-ben 616 millió, 1967-ben 356 millió forint, azóta folyamatosan nô, jelenleg évi tízmilliárd (!) forint körül van, miközben az utasforgalom gyakorlatilag alig változott (BKV közlés).

Ezek a tagadhatatlan eredmények azonban csak , halasztással" és a minổég csökkentésével voltak elérhetốk. Az a pótlólagos baj származott ebbốl, hogy a gazdaságirányítási reformmal járó föllendülés mintegy axiómaként támaszkodott az ellenkezôjére - vagyis a ráfordításnövekedést automatikusan azonosnak vette a minôségjavulással (pl. lakásépités, karbantartás, közlekedéstámogatás stb.), és így erỡs lökést adott a ráfordítások emelkedésének.

2 Nem elhanyagolható a dolog területi mellékhatása sem. A telephely - leszorított termelési értéke miatt - a településfejlesztésben csökkentett mértékben vesz részt. A teljes termelési vertikum hiánya miatt a telephelyeken nincsenek magasszintử szervező́-irányitó funkciők, ami természetessé teszi a magasabb végzettségứek elvándorlását.

3 Egy bányany itáshoz éppoly természetesen hozzátartozik a bányászlakásoképítése, mint ahogy egy textilüzem letelepítéséhez nem tartozik hozzá. Viszont a lakásépités termelési (beruházási) költségként nem fog megjelenni.

4 Hogy ez mennyire nem így van, gondoljunk az elértéktelenedô ózdi lakásokra, vagy arra, milyen hirtelen megszünt az állami lakásépítés, midổn az iparfejlesztés stratégiája a nyolcvanas években megváltozott.

s Igen jó példa erre a kisforgalmú vasutak felszámolásának programja. A fô hivatkozás a vasútfelszámolásra az volt, hogy állaguk igen elavulı (mintegy tízmilliárd forint kellett volna a felújításhoz), hogy a kis forgalom az üzemeltetést nem teszi gazdaságossá, és hogy a forgalom átterelése gépjármũvekre beleilleszkedik az egyébként is folyó közútfejlesztési- és energiaátalakitási programba (szénhidrogén-felhasználás emelése).

Valószínúleg ösztönzést nyert ez a program a nagy angliai vasútfelszámolástól is - mindenesetre ,,modernizációnak" nevezte és tekintette magát. Saját ágazati értelmezésben joggal: a fổvonalak korszerúsítése, pályaudvari rekonstrukciók, villamosítás, áj biztonsági és jelzôberendezések stb. jól indokol hatóak voltak a költségvetés számára a források biztosítására. A tárcának ugyanakkor bizonyítania kellett, hogy gazdálkodik, vagyis fólszámolja a nem kifizetổdổ tevékenységeket. Így a felszámolás alapja egy üzemgazdasági mérlegelés lett, méghozzá a vasutat gya- 
korlatilag önálló tớkés vállalkozónak tekintve (holott nem az, hanem költségvetési szerv). Tehát:

— igen alacsony szénhidrogén-árakkal számolt (ezt 1973-tól ugyan elsöpörte az olajárrobbanás, de a koncepciónak meg se kottyant);

- a közútépítés -karbantartás költségeit, a közúti tömegközlekedés létesítményeit nem vette figyelembe (tárcaidegen kiadás lévén);

- a szállítási többletköltségeket az igénybe vevôkre hárította (pl . a személyszállításnál minimális kompenzációval, a teherszállításnál semmilyennel);

- a tényleges lakossági vagy termelôi igényeket gyakorlatilag fỉgyelembe se vette.

- A , területfejlesztés gazdaságossága" igen homályos értelmú, ha általánosságában - a maga teljes társadalmi jelentésében - vesszük. Ellenben egy-egy körülhatárolt termelési résztevékenységre viszonylag jól meghatározható. Persze csak rövid idốtávra és csak akkor, ha maga a kiemelt tevékenység is gazdaságos. Az elmúlt évtizedekben ez az utóbbi feltétel, mint ma már világos, sajnos egyértelmủen nem teljesült, és ez a fejlesztés jeleutôs térségek lerobbanásához vezetett (elavult termelésszerkezet, elértéktelenedô infrastruktúra, eltorzított társadalom-szerkezet és értékrend).

7 Az infrastruktúra-fejlesztés fajlagos költsége a fờvárosban messze a legmagasabb, és az üzemek hozzájárulása ehhez aránytalanul alacsony. Ezáltal nem érzékelik az infrastruktúra szükösségét, és nem is érdekeltek a másutt történó fejlesztésben. (Csak egy példa: telefonhoz mérhetetlenül könnyebb egy vállalatnak a fôvárosban hozzájutni, mint egy vidéki kisvárosban, noha ott nagyobb szükség van rá, és olcsóbb is a fejlesztés.) Természetesen, ettổ függetlenül létezett az iparfejlesztésre kulcsolt infrastruktúra-fejlesztés szisztémája is, ellentétes hatással. Az ellentét azonban csak látszólagos. A fỏvárosból történố kitelepítést végeredményben egyedül a munkaeróhiány, és nem az infrastruktúra-hiány motiválta, így a kitelepítés erôforrás-felhasználás szempontjából olyan eltorzult eredményeket hozott, amit például az ipar budapesti függôsége igen jól szemléltet.

8 Az egyenlôtlen elosztás normatív alapja a település-hierarchia. A hierarchia az ellátás ésszerüsítésének gondolatán alapul. Az ellátásnak különféle szintjei vannak: alsófokú (általános iskola, körzeti orvos); középfokú (középiskola, kiskórház, rendelő̉intézet); felsổfokú (fóiskola, nagykórház). Ezek a szintek célszerủen a megfelelô szintử településben összegzendók. Mivel a magasabb hierarchikus szinten levố település ,,nagyobb körzet lakosságát látja el”, indokolt, hogy a fejlesztési eszközökbôl is többet kapjon. Az egy lakosra jutó fejlesztési összegek településtipusonkénti arányai a hatvanas és a hetvenes évtizedben a következốképpen állandósultak (saját számításaim szerint): ún. szerepkör nélküli település alsófokú központ kiemelt alsófokú-részleges középfokú központ

1

$3-6$

$5-20$

$10-30$

$40-80$

felsôfokú központ (gyakorlatilag megyeszékhely)

Az arányok jórészt abból alakultak ki, hogy a fejlesztés hozzávetôlegesen fele a lakásépítésre ment, ez pedig a városokra - illetve elsőssorban a megyeszékhelyekre - koncentrálódott. A ,futottak még" kategória szerepkör nélküli településeibốl a tanácsi székhelyközség nem ritkán még a községfejlesztési alapot is elvonta. Így aztán a megyeszékhelyek, ,,ésszerûség szerinti” fontosságuknak megfelelổen, a megyéjükre esố fejlesztési összegnek körülbelül a felét kapták.

9 Az úgynevezett ,,intézmény-központosítás" fổ adatai:

\begin{tabular}{lrrr}
\hline & 1965 & 1980 & 1985 \\
\hline Települések száma & 3259 & 3121 & 3058 \\
ebbốl nem rendelkezik: & 339 & 1597 & 1556 \\
- helyi tanáccsal & 48 & 828 & 924 \\
- iskołával & $\mathrm{kb} .200$ & $\mathrm{~kb} .1500$ & $\mathrm{~kb} .1800$ \\
\hline önálló termelôszövetkezettel & &
\end{tabular}

(Statisztikai Évkönyvek alapján.)

Mintegy 1700 községben nincs körzeti orvos. Az ÁFÉSZ-ek száma eme 20 év alatt 1370-ról 270-re csökkent jelentốsen távolodván azoktól a termelốktổl, akiktôl a felvásárlást eszközölniük kell, és a fogyasztóktól, akiknek az ellátását biztosítaniuk kellene. Nem igazán éri meg - szigorúan kereskedelmi szempontból — ellátni ezeket a falvakat, oly kicsi a forgalom. (Noha valaha a szatócsnak megérte.)

10 A nemzetgazdaság növekedés-orientációjának egyik fontos vadhajtása a beruházási és a fenntartási költségek , ,kemény" elválasztása, az elổzô értelemszerú preferálásával. Így lett , ,gazdaságosabb” egy centralizált új létesítmény a már meglévớ réginél. 
" Néhány alapvetố tényezô:

- A migráció ösztönzése városi lakásépítéssel és

- munkahely-teremtéssel, a falvak funkcióktól való megfosztása;

- Az ingázás. 1960-80 között az ingázók idôráfordítása mint "externalitás", a kétszeresére nốtt. Az ingázásra késztetố szívás jellegzetesen függ a centrum fejlettségétôl. 1980-as adatok szerint a (napi) ingázási idố a teljes munkaidôalapnak (nemcsak az ingázókénak):

- országosan

- Budapesten $1,50 \%-a$,

- alföldi kisvárosban $2,00 \%-a$,

- Az ingatlanértékek relatív viszonyának változása (,,ingatlanolló”). Az értékek nemcsak szélsóségesen különböznek, hanem szélsốséges ütemben , nyílnak" is. Egy aprófaluban és a Rózsadombon meghatározható telekár egy évtized alatt 1000 -szeresrổ 8000 -szeresre nốtt. A lakásárakkal is hasonló a helyzet, csak az összehasonlitás — pl. az eltérố komfortossági szint miatt — nehezebb. Mindenesetre ma a, ,rớzsadombi" lakás m² ára 50.000, Ft körül van, parasztházat - helyétổ erốsen függốen - joval 1000,- Ft alatti $\mathrm{m}^{2}$-áron is lehet már venni (saját tapasztalat alapján).

Az ingatlanol ló nyílásának számos hatása közül emeljük ki azt, hogy a magánerốs fejlesztőeszközöket a községekbốl - ahol megteremtödtek - a centrumokba vonzza. Ez eredetileg egzisztenciális kényszerũség volt, a migrációval függött össze, de ma már jól látható, elsõsorban Budapest térségében, hogy értékmentố funkciót is betölt, azaz üzleti szempontból is érdemes központokban beruházni. Ez a folyamat a centrumok már amúgy is igen problematikus lakáspiacát rövid idốn belül teljesen felboríthatja (mindenekelôtt a fốvárosban).

12 Kolosi Tamás kategóriái szerint a társadalmi összetétel a következố (a ,,szélsố” kategóriákban):

\begin{tabular}{lcc}
\hline \multicolumn{1}{c}{$\%$} & város & falu \\
\hline elit & 17,7 & 0,6 \\
deprivált & 4,0 & 24,9 \\
\hline Összesen & 100,0 & 100,0 \\
\hline
\end{tabular}

Az iskolai végzettség, a lakásviszonyok, a jövedelemeloszlás pontosan megfelel ennek a képnek (falun ugyanazért a munkáért $42 \%$-kal kap kevesebbet az ember - Vécsei Pál 1981).

A falvak kezdik elveszteni értelmiségüket. Felsôfokú végzettséggel az ország lakosainak 10, a gyenge pozíciojuú falvak népességének 0,3\%-a rendelkezik. 1970-80 között a falvak egyötödében az értelmiségiek aránya nemcsak elmaradt az országos átlagos változástól, hanem csökkent (Vécsei Pál közlése).

A migrációs hullámok miatt elvész a lokális kőtôdés. Az aspirációk és az értékrend rövidtávú érdekek mentén rögzốdnek.

13 A forrásérzéketlenség miatt az államszocialista szisztémában a ráfordítás mindig meghaladja az eredményt, és így a következó jellegzetes, 4 fokozatú fejlôdési pálya alakul ki: (7. ábra)

- Az elsố fázisban a növekedés biztosítható a belsõ források fokozott igénybevételével.

- A második fázisban a ráfordítások volumene már meghaladja az eredményt. Ez csak külsổ igénybevétellel (hitel) lehetséges. Mindenesetre az eredmény még mindig nố.

- A harmadik fázisban a külsố forrás már nem nố (kimerült, vagy önmaga prolongálására szolgál a hitel). Az eredmény azonban többféle okból, mint pl. a hitelek törlesztési kényszere, még nem csökken. Ez most már csakis belsố takarékossággal, ráfordítás csökkentésssel érhetổ el. Itt válik kényszerré a struktúraátalakítás. (Megítélésem szerint mind a lengyel, mind a magyar gazdaság e fázisban van jelenleg.)

- A negyedik fázisban már nincs az a kényszertakarékosság, amely a hanyatlást - a GNP csőkkenését - megállíthatná. Másrészt: a tartalékok fỏlélése itt már oly elörehaladott, hogy a struktúraváltoztatásnak alig van esélye. (A román gazdaság föltehetóen már ebben a fázisban van.)

14 Az 1975-ben induló V. ötéves tervben - az igazi nagy hitelfelvételekkel egyidejûleg - jelentősen csökkentették az iparkitelepítés akcióterületeit, mindazon járulékos beruházásokkal, amelyek a szisztémában ehhez tartoznak. Az iparkitelepítésre fordított összeg egy milliárdról a negyedére csökkent.

is Az iparvállalatok racionalizáló törekvései nem ritkán az avult eszközkészletư vidéki telephely bezárását eredményezik. A termeléscsökkentéssel járó létszámcsökkentés elsôsorban a vidéki ingázókat sújtja, fởleg az alacsonyabban kvalifikáltakat (kiemelten a cigányokat). Így ma és várhatóan a jövóben is az eddig is elmaradottnak számító térségekben a legnagyobb a munkanélküliség, és - az adottságok szinte minden oldalú hiánya (megszüntetése) miatt 
a legnehezebb a segítség. Az ipar szerkezet átlakítási koncepciója a legteljesebb mértékben a fejlett iparú térségekrє összpontosít, úgy háromnegyed részben kifejezetten a fổvárosra.

Az infrastruktúra-hiány és a lakáshiány viszont alapvetố akadályt jelent abban, hogy a népesség elvándoroljor. a kedvezổbb lehetổségeket ígérố településekbe.

16 A program 1985-ben indult, mintegy 500 településre, 5 év alatt 3 milliárd forint felhasználható forrással. Magyarországon ez az elsố ilyen program. Annakelốtte is volt ugyan efféle deklarált cél, de az gyakorlatilag mindig teljeser beleolvadt az iparfejlesztési programba, és ilyen módon a nem rövidtávú hatásai mindig kettôs arcúak voltak (lásc „,szivattyúhatás”). Attól tartok, ez a most folyó program is elcsúszik ebbe az irányba; infrastruktúra-fejlesztésrє $\mathrm{pl}$. lényegében nem használható fel az alap. Márpedig jelen helyzetünkben az extenzív iparfejlesztésnek már való. színúleg rövidtávú elônyei sincsenek.

17 A ,,fölélés" néhány társadalmi tényezôje:

1. a mortalitás és morbiditás erôs növekedése:

- a születéskor várható élettartam férfiaknál 65,5 év (Európában a legalacsonyabb);

- az élveszületési arány 1000 lakosra 12,2, nem biztosítja a reprodukciót, az ország népessége fogy;

- az aktív alkoholisták száma 600 ezer;

— az öngyilkosok aránya 100 ezer fơre 45 (a világon a legmagasabb);

- neurotikus a 6-14 éves korosztályok háromnegyede;

- katonai szolgálatra egészségügyileg alkalmatlan a sorkötelesek egyharmada.

2. az életminôség zavarai:

- a minőség társadalmi méretứ leértékelődése;

- a modernizációs igény eltorlaszolása;

- morális válság;

- értéktorzulás.

3. a lokalitás leértékelôdése:

- a falusi közösség társadalmi zárvánnyá torzulása;

- az értelmiségi exodus miatt megszűnổ mũvelốdési minta;

- az elvándorlással esökkenô kisüzemi mezôgazdasági kompenzációs hinterland;

- a helyi tradíciók értékének elenyészte;

- a falusi lakásvagyon relatív leértékelơdése (a veszteség a leszakadóban lévố falvakban 1970 és 1980 közöt az országos átlaghoz képest mintegy 200 milliárd forint).

\section{Irodalom}

Kornai J. (1982) A hiány (Budapest: Közgazdasági és Jogi Könyvkiadó)

Miklóssy E. (1987) ,Településhálózatunk a hetvenes évtizedben” Palócföld 4.

Vécsei P. (1981) A területi fejlôdés általános törvényszerũségeinek feltárása, VÁTI. 


\section{INTERNAL COLONIZATION OF HUNGARY}

\section{ENDRE MIKLÓSSY}

A well-known feature of state socialist national economy is its lack of cost-sensitivity. More precisely, this stands, first of all, for externalities: the key actors of economic life tend to charge the ,,second fiddlers" with the extra costs of forced growth. As a matter of fact, all individuals, all activities, all fields and settlements which do not fall in the ,, mainstream" of the centralizing policy, are second fiddlers. The major instrument of charging extra costs with secondary actors is the mechanism of , spatial pump". The objective is to increase the relative profit of protagonists and decrease their relative costs at the expense of others. Obviously, this is only possible by political and economic pressure that stabilizes the quasi-colonial dependence of ,,peripheries".

Examples for the means of profit-increasing: gap between the relative prices of agricultural and industrial products, subsidized production, and the system of industrial branch-plants. Examples for cost-decreasing: central redistribution named as ,,development policy" including housing projects, institutional concentrations and financial dispreferencies. The ideology of underdeveloping peripheries is expressed by ,,rephasing", i.e. postponing the tasks.

Besides the persisting system of interests in centralization, growing general expenses of the national economy themselves are now increasingly in the way of financing a real catching-up development. Finally, the general decline of peripheries questions reckonable economic results. There is no other solution to the problem than making externalities internal, i.e. costsensitivity.

Transl. E. Daróczi 